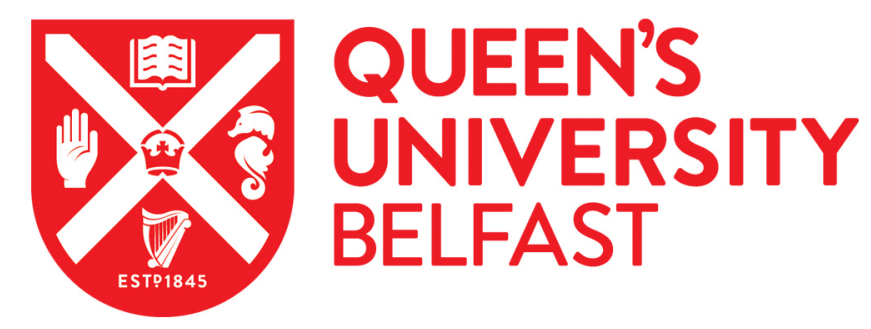

\title{
Uptake of Zn by arbuscular mycorrhizal white clover from Zn- contaminated soil
}

Zhu, Y. G., Christie, P., \& Laidlaw, A. S. (2001). Uptake of Zn by arbuscular mycorrhizal white clover from Zncontaminated soil. Chemosphere, 42, 193-199.

\section{Published in:}

Chemosphere

Queen's University Belfast - Research Portal:

Link to publication record in Queen's University Belfast Research Portal

\section{General rights}

Copyright for the publications made accessible via the Queen's University Belfast Research Portal is retained by the author(s) and / or other copyright owners and it is a condition of accessing these publications that users recognise and abide by the legal requirements associated with these rights.

Take down policy

The Research Portal is Queen's institutional repository that provides access to Queen's research output. Every effort has been made to ensure that content in the Research Portal does not infringe any person's rights, or applicable UK laws. If you discover content in the Research Portal that you believe breaches copyright or violates any law, please contact openaccess@qub.ac.uk. 


\title{
Uptake of Zn by arbuscular mycorrhizal white clover from Zn-contaminated soil
}

\author{
YongGuan Zhu ${ }^{\text {a,* }}$, Peter Christie ${ }^{\text {a }}$, A. Scott Laidlaw ${ }^{b}$ \\ a Department of Agricultural and Environmental Science, The Queen's University of Belfast, Newforge Lane, Belfast BT9 $5 P X, U K$ \\ ${ }^{\mathrm{b}}$ Department of Applied Plant Sciences, The Queen's University of Belfast, Newforge Lane, Belfast BT9 5PX, UK
}

\begin{abstract}
A randomised block glasshouse pot experiment compared the growth and $\mathrm{Zn}$ uptake of mycorrhizal and nonmycorrhizal white clover plants grown in a sterile soil/sand mixture containing $25 \mathrm{mg} \mathrm{Zn} \mathrm{kg}^{-1}$ to which five application rates of $\mathrm{Zn}\left(\right.$ as $\mathrm{ZnSO}_{4}$ ) from 0 to $400 \mathrm{mg} \mathrm{kg}^{-1}$ were made. Two mycorrhizal inocula infected roots from the field and from clover trap cultures, were compared. Mycorrhizal infection (ranging from $33 \%$ to $46 \%$ of total root length) and $\mathrm{Zn}$ application had little effect on plant growth. Increasing $\mathrm{Zn}$ application rate led to increased uptake of $\mathrm{Zn}$ in roots and shoots (especially roots), but the increases were significantly greater in non-mycorrhizal controls than in mycorrhizal treatments. In contrast, P uptake was higher in mycorrhizal than in non-mycorrhizal plants. Plants that received trap culture inoculum had significantly lower $\mathrm{Zn}$ uptake than those that received field inoculum. The results indicate that mycorrhizal infection may have exerted some protective effect against plant $\mathrm{Zn}$ accumulation at the range of soil $\mathrm{Zn}$ concentrations studied and may have immobilised $\mathrm{Zn}$ in or near the roots to some extent. However, this mycorrhizal effect cannot be explained simply by tissue dilution, hyphal sequestration or root immobilisation of $\mathrm{Zn}$. (C) 2000 Elsevier Science Ltd. All rights reserved.
\end{abstract}

Keywords: Arbuscular mycorrhiza; Inoculum type; Soil pollution; White clover; Zinc

\section{Introduction}

The principal effect of arbuscular mycorrhiza in agricultural production systems and natural ecosystems is in most cases the capability to supply the host plant with mineral nutrients that are relatively immobile in the soil, particularly phosphorus and trace elements ( $\mathrm{Li}$ et al., 1991; Jakobsen et al., 1994). In a glasshouse experiment, Thompson (1996) demonstrated that arbuscular mycorrhizal inoculation could correct dual phosphorus and zinc deficiencies of linseed plants. However, elevated concentrations of heavy metals exist in many agricultural soils from anthropogenic sources

\footnotetext{
${ }^{*}$ Corresponding author. Tel.: +61-8303-7436; fax: +618303-6511.

E-mail address: yongguan.zhu@adelaide.edu.au(YG. Zhu).
}

such as sewage sludge application (McGrath, 1987) or mining activities (Shetty et al., 1995; Weissenhorn et al., 1995 ) and this poses long-term risks to environmental quality and sustainable food production. It has been widely reported that ectomycorrhizal and ericoid mycorrhizal fungi can increase the tolerance of their host plants to heavy metals when these are present at toxic levels (Bradley et al., 1981, 1982; Jones and Hutchinson, 1988a,b). The underlying mechanism of the enhancement of plant tolerance to heavy metal contamination is thought to be the binding capacity of fungal hyphae to metals in the roots or in the rhizosphere. This immobilises the metals in or near the roots and thus decreases their translocation to the shoots (Bradley et al., 1981; Brown and Wilkins, 1985; Wasserman et al., 1987). As far as the role of arbuscular mycorrhiza in plant heavy metal uptake is concerned, no firm general conclusions have been drawn. 
In some reports it has been claimed that arbuscular mycorrhiza may also help plants to tolerate high levels of soil heavy metal contamination. For example, Heggo et al. (1990) and Hetrick et al. (1994) were able to demonstrate that at high soil heavy metal concentrations, arbuscular mycorrhizal infection reduced the concentrations of $\mathrm{Zn}, \mathrm{Cd}$ and $\mathrm{Mn}$ in plant leaves. However, there has been no published evidence showing the quantitative relationship between mycorrhizal infection and plant tolerance to heavy metal pollution under controlled conditions. The present study was therefore, designed to investigate the effects of different levels of soil $\mathrm{Zn}$ contamination on the infection of white clover by indigenous arbuscular mycorrhizal in glasshouse conditions and the relationship between mycorrhizal infection and plant heavy metal tolerance.

\section{Materials and methods}

\subsection{Soil preparation}

Soil was collected from a mixed perennial ryegrass (Lolium perenne L.) and white clover (Trifolium repens L.) sward in a long-term field experiment at the Agricultural Research Institute of Northern Ireland at Hillsborough, County Down (Irish Grid Reference J244577). The soil was a sandy clay loam derived from Silurian shale and is typical of a large area of County Down. Moist samples removed from the top $10 \mathrm{~cm}$ of the soil profile were passed through a $0.5-\mathrm{cm}$ sieve, and large stones and plant root debris were removed. The soil was then thoroughly mixed and sterilised with $10 \mathrm{kGy}$ of $\gamma$-irradiation using a ${ }^{60} \mathrm{Co}$ source. The soil contained $50 \mathrm{mg}$ 'total' (aqua-regia - extractable)

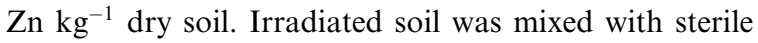
(autoclaved) acid-washed sand in a 50:50 w/w ratio to aid drainage and aeration. Aliquots of the soil/sand mixture were amended with five levels of $\mathrm{Zn}$ addition: 0 , 50, 100, 200 and $400 \mathrm{mg} \mathrm{kg}^{-1}$ soil as $\mathrm{ZnSO}_{4}$ solution. $\mathrm{K}_{2} \mathrm{SO}_{4}$ solution was also applied at the appropriate rates to balance the quantity of S added to each treatment and thus prevent plant yield responses to $\mathrm{S}$.

\subsection{Mycorrhizal inocula}

Two types of inoculum were compared. Field inoculum comprised fresh roots collected from the same field from which the soil was obtained. The roots were derived from areas dominated by white clover, but some roots of other species, especially perennial ryegrass, would have been present. The second type of inoculum consisted of fresh roots of white clover from trap culture using the same clover cultivar as in the pot experiment.

\subsection{Glasshouse experiment}

Four three-week old white clover seedlings ( $T$. repens cv. Grasslands Huia) were transferred to each $9-\mathrm{cm}$ plastic plant pot containing $300 \mathrm{~g}$ of soil/sand mixture. A mycorrhiza inoculum pad ( $0.3 \mathrm{~g}$ of fresh roots) was placed immediately around the root systems. $10 \mathrm{ml}$ of a suspension of Rhizobium leguminosarum biovar. trifolii were added to each pot to ensure effective nodulation of the roots. The experiment consisted of five levels of $\mathrm{Zn}$ addition $\left(0,50,100,200\right.$ and $\left.400 \mathrm{mg} \mathrm{kg}^{-1}\right)$ and three mycorrhizal treatments (no inoculum, field inoculum and trap culture inoculum), giving 15 treatments with ten replicates in a fully randomised block. The pots were adjusted regularly to field capacity using tap water. Mercury vapour lamps provided an additional 150$400 \mu \mathrm{mol} \mathrm{m}{ }^{-2} \mathrm{~s}^{-1}$ of photosynthetically active radiation (PAR) at pot level from 8 to 16 each day. Supplementary heating was used to maintain a minimum temperature of $10^{\circ} \mathrm{C}$. The plants were harvested after 20 weeks. The shoots were removed by cutting just above the soil surface. The roots were recovered by washing with de-ionised water. Roots and shoots were weighed after oven drying at $70^{\circ} \mathrm{C}$ overnight and then ground to $<0.25 \mathrm{~mm}$.

\subsection{Chemical analysis of plant material}

Subsamples of ground oven dried roots and shoots were digested in a mixture of nitric and perchloric acids to destroy the organic matter (Ministry of Agriculture, Fisheries and Food, 1986). Multi-element analysis, including $\mathrm{P}$ and $\mathrm{Zn}$, was then performed using inductively coupled plasma-atomic emission spectroscopy (ICPAES).

\subsection{Determination of mycorrhiza infection}

Subsamples of washed plant roots were gently dried with tissue paper and preserved in formalin-glacial acetic acid-ethanol (12.5:12.5:200 v/v). Prior to examination, roots were cut into $2-\mathrm{cm}$ bundles and rinsed under tap water. Randomly selected root segments were then cleared in $5 \% \mathrm{v} / \mathrm{v} \mathrm{KOH}$ for $60 \mathrm{~min}$ at $90^{\circ} \mathrm{C}$, followed by thorough washing with water. The cleared root segments were soaked overnight in $1 \% \mathrm{v} / \mathrm{v} \mathrm{HCl}$ at room temperature and placed in the stain solution $(0.05 \% \mathrm{w} / \mathrm{v}$ Trypan blue in lactoglycerol) for $15 \mathrm{~min}$ at $60^{\circ} \mathrm{C}$. Stained root segments were mounted on microscope slides under coverslips. A magnified intersection method (McGonigle et al., 1990) was used to determine the proportion of root length infected. Five stained root segments were aligned perpendicular to the long axis of each slide and observed at $\times 200$ magnification. The field of view was moved systematically without looking through the microscope so that 50 intersections between 
roots and a vertical eyepiece cross hair were counted as either negative or positive (i.e. with arbuscules, vesicles or hyphae) per slide. Three slides were examined for each treatment, giving a total of 150 counts per sample as recommended by McGonigle et al. (1990).

\section{Results}

\subsection{Mycorrhiza infection}

No infection was observed in the uninoculated control plants. Table 1 shows that the mean proportion of root length infected in inoculated plants ranged from $33 \%$ to $46 \%$ and there was no significant difference between field and trap culture inocula. There seemed to be a slight trend of increasing infection with increasing addition of $\mathrm{Zn}$ to the soil, but the only treatment that showed a significant difference from the unamended control was the highest application rate of $\mathrm{Zn}$ combined with trap culture inoculum. Thus, in general, there was little effect of $\mathrm{Zn}$ application rate on mycorrhiza infection rate, and there was certainly no depression of infection resulting from the moderate rates of $\mathrm{Zn}$ contamination of the soil studied.

\subsection{Root and shoot yields}

Mycorrhizal plants treated with trap culture inoculum had lower shoot yields than non-mycorrhizal controls, and mycorrhizal plants treated with field inoculum had higher root yields than non-mycorrhizal controls. Although these yield effects were statistically significant (Table 2), they were small. There was no consistent trend between $\mathrm{Zn}$ application rate and shoot yield, but at the highest $\mathrm{Zn}$ application rate $\left(400 \mathrm{mg} \mathrm{kg}^{-1}\right)$ there tended to be a decrease in shoot yield (not significant for trap culture incoculum). Application of $\mathrm{Zn}$ had little effect on root yield.

\subsection{Shoot and root $P$ concentrations}

Mycorrhizal plants had higher shoot and root $\mathrm{P}$ concentrations than non-mycorrhizal controls (Table 3). Mycorrhizal plants that received trap culture inoculum had higher root and shoot $\mathrm{P}$ concentrations than those treated with field inoculum. The highest $\mathrm{Zn}$ application rate gave higher shoot and root $\mathrm{P}$ concentrations than did any other application rate.

\subsection{Root and shoot Zn concentrations}

The highest $\mathrm{Zn}$ shoot concentrations were found in the non-mycorrhizal control plants, with significantly lower concentrations in those treated with field inoculum and the lowest concentrations in plants that received trap culture inoculum (Table 4). Root $\mathrm{Zn}$ concentrations were also significantly higher in nonmycorrhizal than in mycorrhizal plants, but there was no effect of inoculum type on root $\mathrm{Zn}$ concentration. There were clear increases in shoot and root $\mathrm{Zn}$ concentrations with increasing $\mathrm{Zn}$ application rate to the soil. Zinc concentrations were higher in the roots than in the shoots.

\subsection{Root and shoot Zn uptake}

Table 5 shows that the plant $\mathrm{Zn}$ uptake results broadly reflect the root and shoot $\mathrm{Zn}$ concentrations because of the small effects of infection and $\mathrm{Zn}$ application on root and shoot yields. However, marked differences between inoculum types are now evident in both roots and shoots, with lower $\mathrm{Zn}$ uptake occurring in both roots and shoots of plants receiving trap culture than in those treated with field inoculum. Shoot and root $\mathrm{Zn}$ uptakes were similar when no $\mathrm{Zn}$ was applied but as $\mathrm{Zn}$ application rate increased, shoot $\mathrm{Zn}$ uptake increased much less than root $\mathrm{Zn}$ uptake and the decrease in $\mathrm{Zn}$ uptake by mycorrhizal roots and shoots compared with controls became more pronounced.

Table 1

Mycorrhiza infection rates of white clover roots (percentage of total root length infected)

\begin{tabular}{|c|c|c|c|c|c|}
\hline \multirow[t]{2}{*}{ Inoculum type } & \multicolumn{5}{|c|}{ Added $\mathrm{Zn}\left(\mathrm{mg} \mathrm{kg}^{-1}\right.$ soil/sand) } \\
\hline & 0 & 50 & 100 & 200 & 400 \\
\hline Field inoculum & 40.9 & 33.9 & 39.1 & 40.0 & 46.1 \\
\hline Trap culture inoculum & 36.0 & 32.9 & 38.4 & 37.8 & 49.6 \\
\hline Standard error & & & 3.62 & & \\
\hline \multicolumn{6}{|l|}{ Significance ${ }^{a}$ due to: } \\
\hline Inoculum type & & & NS & & \\
\hline $\mathrm{Zn}$ application rate & & & $* *$ & & \\
\hline Inoculum type $\times \mathrm{Zn}$ rate & & & NS & & \\
\hline
\end{tabular}

\footnotetext{
${ }^{a}$ By analysis of variance; **, $P<0.01$; NS, not significant.
} 
Table 2

Effect of mycorrhizal infection and added $\mathrm{Zn}$ on white clover shoot and root yield (g DM pot ${ }^{-1}$ )

\begin{tabular}{|c|c|c|c|c|c|}
\hline \multirow[t]{2}{*}{ Inoculum type } & \multicolumn{5}{|c|}{ Added $\mathrm{Zn}\left(\mathrm{mg} \mathrm{kg}^{-1}\right.$ soil/sand) } \\
\hline & 0 & 50 & 100 & 200 & 400 \\
\hline \multicolumn{6}{|l|}{ Shoots } \\
\hline No inoculum (control) & 3.98 & 3.63 & 3.83 & 3.86 & 3.53 \\
\hline Field inoculum & 3.78 & 3.83 & 3.89 & 3.75 & 3.21 \\
\hline Trap culture inoculum & 3.51 & 3.77 & 3.60 & 3.68 & 3.30 \\
\hline Standard error & & & 0.121 & & \\
\hline \multicolumn{6}{|c|}{ Significance ${ }^{\mathrm{a}}$ of differences due to: } \\
\hline Inoculum type & & & $*$ & & \\
\hline $\mathrm{Zn}$ application rate & & & $* * *$ & & \\
\hline Inoculum type $\times \mathrm{Zn}$ rate & & & NS & & \\
\hline \multicolumn{6}{|l|}{ Roots } \\
\hline No inoculum (control) & 1.33 & 1.19 & 1.36 & 1.31 & 1.29 \\
\hline Field inoculum & 1.48 & 1.41 & 1.44 & 1.51 & 1.39 \\
\hline Trap culture inoculum & 1.33 & 1.24 & 1.32 & 1.38 & 1.30 \\
\hline Standard error & & & 0.051 & & \\
\hline \multicolumn{6}{|c|}{ Significance ${ }^{\mathrm{a}}$ of differences due to: } \\
\hline Inoculum type & & & $* * *$ & & \\
\hline Zn application rate & & & $*$ & & \\
\hline Inoculum type $\times \mathrm{Zn}$ rate & & & NS & & \\
\hline
\end{tabular}

${ }^{a}$ By analysis of variance; *, $P<0.05 ; * * *, P<0.001$.

Table 3

Effect of mycorrhizal infection and added $\mathrm{Zn}$ on white clover shoot and root P concentration (\% DM)

\begin{tabular}{|c|c|c|c|c|c|}
\hline \multirow[t]{2}{*}{ Inoculum type } & \multicolumn{5}{|c|}{ Added $\mathrm{Zn}$ (mg kg${ }^{-1}$ soil/sand) } \\
\hline & 0 & 50 & 100 & 200 & 400 \\
\hline \multicolumn{6}{|l|}{ Shoots } \\
\hline No inoculum (control) & 0.094 & 0.092 & 0.100 & 0.097 & 0.112 \\
\hline Field inoculum & 0.146 & 0.142 & 0.156 & 0.155 & 0.180 \\
\hline Trap culture inoculum & 0.165 & 0.153 & 0.170 & 0.163 & 0.198 \\
\hline Standard error & & & 0.0053 & & \\
\hline \multicolumn{6}{|c|}{ Significance of differences due to: } \\
\hline Inoculum type & & & $* * *$ & & \\
\hline Zn application rate & & & $*$ & & \\
\hline Inoculum type $\times \mathrm{Zn}$ rate & & & NS & & \\
\hline \multicolumn{6}{|l|}{ Roots } \\
\hline No inoculum (control) & 0.108 & 0.109 & 0.109 & 0.108 & 0.130 \\
\hline Field inoculum & 0.198 & 0.189 & 0.205 & 0.198 & 0.227 \\
\hline Trap culture inoculum & 0.213 & 0.197 & 0.217 & 0.195 & 0.232 \\
\hline Standard error & & & 0.0052 & & \\
\hline \multicolumn{6}{|c|}{ Significance of differences due to: } \\
\hline Inoculum type & & & $* * *$ & & \\
\hline $\mathrm{Zn}$ application rate & & & $* * *$ & & \\
\hline Inoculum type $\times \mathrm{Zn}$ rate & & & NS & & \\
\hline
\end{tabular}

\section{Discussion}

Our results are in broad agreement with those of Heggo et al. (1990), who found that mycorrhizal infec- tion of soybean plants increased foliar P uptake and decreased $\mathrm{Zn}$ uptake in highly polluted soils. They also found increases in foliar $\mathrm{P}$ concentration and decreases in foliar $\mathrm{Zn}$ concentration in soils with higher $\mathrm{Zn}$ con- 
Table 4

Effect of mycorrhizal infection and added $\mathrm{Zn}$ on clover shoot and root $\mathrm{Zn}$ concentration $\left(\mathrm{mg} \mathrm{kg}^{-1} \mathrm{DM}\right)$

\begin{tabular}{|c|c|c|c|c|c|}
\hline \multirow[t]{2}{*}{ Inoculum type } & \multicolumn{5}{|c|}{ Added $\mathrm{Zn}\left(\mathrm{mg} \mathrm{kg}^{-1}\right.$ soil/sand) } \\
\hline & 0 & 50 & 100 & 200 & 400 \\
\hline \multicolumn{6}{|l|}{ Shoots } \\
\hline No inoculum (control) & 22.7 & 67.7 & 100.5 & 126.0 & 235.9 \\
\hline Field inoculum & 25.9 & 40.6 & 51.8 & 83.9 & 167.3 \\
\hline Trap culture inoculum & 19.3 & 41.3 & 49.0 & 65.2 & 116.0 \\
\hline Standard error & \multicolumn{5}{|c|}{3.85} \\
\hline \multicolumn{6}{|c|}{ Significance of differences due to: } \\
\hline Inoculum type & & & $* * *$ & & \\
\hline $\mathrm{Zn}$ application rate & & & $* * *$ & & \\
\hline Inoculum type $\times \mathrm{Zn}$ rate & & & $* * *$ & & \\
\hline \multicolumn{6}{|l|}{ Roots } \\
\hline No inoculum (control) & 69.5 & 257.4 & 402.0 & 605.5 & 1123.4 \\
\hline Field inoculum & 53.6 & 120.5 & 178.0 & 273.1 & 637.2 \\
\hline Trap culture inoculum & 61.9 & 106.2 & 170.9 & 243.1 & 538.7 \\
\hline Standard error & & & 35.47 & & \\
\hline \multicolumn{6}{|c|}{ Significance of differences due to: } \\
\hline Inoculum type & & & $* * *$ & & \\
\hline $\mathrm{Zn}$ application rate & & & $* * *$ & & \\
\hline Inoculum type $\times \mathrm{Zn}$ rate & & & $* * *$ & & \\
\hline
\end{tabular}

Table 5

Effect of mycorrhizal infection and added $\mathrm{Zn}$ on white clover shoot and root $\mathrm{Zn}$ uptake $\left(\mu \mathrm{g}\right.$ pot $\left.^{-1}\right)$

\begin{tabular}{|c|c|c|c|c|c|}
\hline \multirow[t]{2}{*}{ Inoculum type } & \multicolumn{5}{|c|}{ Added $\mathrm{Zn}\left(\mathrm{mg} \mathrm{kg}^{-1}\right.$ soil/sand) } \\
\hline & 0 & 50 & 100 & 200 & 400 \\
\hline \multicolumn{6}{|l|}{ Shoots } \\
\hline No inoculum (control) & 91 & 245 & 381 & 485 & 836 \\
\hline Field inoculum & 98 & 155 & 203 & 315 & 540 \\
\hline Trap culture inoculum & 68 & 156 & 177 & 240 & 382 \\
\hline \multicolumn{6}{|l|}{ Standard error } \\
\hline \multicolumn{6}{|c|}{ Significance of differences due to: } \\
\hline Inoculum type & & & $* * *$ & & \\
\hline Zn application rate & & & $* * *$ & & \\
\hline Inoculum type $\times \mathrm{Zn}$ rate & & & $* * *$ & & \\
\hline \multicolumn{6}{|l|}{ Roots } \\
\hline No inoculum (control) & 92 & 311 & 549 & 800 & 1445 \\
\hline Field inoculum & 79 & 168 & 255 & 408 & 888 \\
\hline Trap culture inoculum & 82 & 130 & 222 & 339 & 697 \\
\hline \multicolumn{6}{|l|}{ Standard error } \\
\hline \multicolumn{6}{|c|}{ Significance of differences due to: } \\
\hline Inoculum type & & & $* * *$ & & \\
\hline Zn application rate & & & $* * *$ & & \\
\hline Inoculum type $\times \mathrm{Zn}$ rate & & & $* * *$ & & \\
\hline
\end{tabular}

tamination from mining activities, and the effect of arbuscular mycorrhiza was related to initial soil metal concentration. The absence of any effect of $\mathrm{Zn}$ application on mycorrhizal infection rate in our experiment may be attributable to the application of inoculum immediately around the roots of the seedlings. This may have promoted root colonisation at an early stage of plant growth. 
According to Smith and Read (1997), a number of different mechanisms may be involved in the interactions between mycorrhizal colonisation and accumulation of heavy metals, including tissue dilution of the toxic element due to interactions with P nutrition (and increased yield), sequestration of the toxic metal in the fungus and development of tolerance by the fungus. In our experiment, tissue dilution is unlikely to have been important because mycorrhizal infection had a relatively small effect on plant yield. The soil Olsen $\mathrm{P}$ concentration was $32 \mathrm{mg}^{-1}$ at the start of the experiment. This would not be considered to be a low available P status and would not be expected to show $\mathrm{P}$ deficiency in non-mycorrhizal or unfertilised treatments, and thus would be unlikely to show a strong yield response to mycorrhizal inoculation. Although there was significantly higher $\mathrm{Zn}$ uptake by roots than by shoots of mycorrhizal white clover plants, both root and shoot uptake were much lower than in non-mycorrhizal control plants in $\mathrm{Zn}$ contaminated soil. Therefore, sequestration by the fungal mycelium cannot account solely for the lower shoot uptake of the metal. Our root samples would have included internal fungal tissue and perhaps some adhering external mycelium. It could be argued that $\mathrm{Zn}$ was sequestered in the bulk external mycelium which was not included in the root samples, but it seems unlikely that this could account for the very marked decrease in root $\mathrm{Zn}$ uptake in inoculated plants. Recent work on Medicago tunculata by Burleigh (personal communication) has indicated that arbuscular mycorrhiza down-regulates a putative lowaffinity $\mathrm{Zn}$ transporter, thus the lower uptake by mycorrhizal clover plants in contaminated soil may be due to the suppression of a gene that controls uptake from high external $\mathrm{Zn}$ concentrations.

It is unlikely that development of tolerance to $\mathrm{Zn}$ by the fungi could explain the results in our short-term experiment. However, trap culture inoculum conferred significantly greater protection to the plants than field inoculum, and this may be due to the development of a more effective suite of fungal species or strains during the growth of the clover plants in the trap cultures.

In summary, we have demonstrated a protective effect of arbuscular mycorrhiza against uptake of potentially toxic $\mathrm{Zn}$ by white clover growing in moderately polluted soil. The level of protection was higher when inoculum was used consisting of white clover roots in which arbuscular mycorrhiza had developed in trap cultures, possibly leading to a more highly specialised relationship between the host and the fungi (from expression of ecological specificity) than with field inoculum (Zhu et al., 2000). It is interesting to note that arbuscular mycorriza seems to protect host plants by reducing uptake of toxic metal into roots and shoots, but hyperaccumulator plant species that have developed tolerance to very high soil metal concentrations show increased translocation of metal to the shoots (Brooks,
1998). Many hyperaccummulators belong to plant families that are often considered to be non-mycorrhizal (for example the Brassicaceae). Further research, including studies on mycorrhizal hyperaccumulator species (if possible), is required to elucidate the mechanism of mycorrhizal protection against toxic elements in soils.

\section{Acknowledgements}

We are very grateful to The Royal Society of London for the award of a Royal Fellowship to Y.G.Z. and to the British Council for support under their Academic Links with China Scheme (project SHA/992/297).

\section{References}

Bradley, R., Burt, A.J., Read, D.J., 1981. Mycorrhizal infection and resistance to heavy metal toxicity in Calluna vulgaris. Nature 292, 335-337.

Bradley, R., Burt, A.J., Read, D.J., 1982. The biology of mycorrhiza in the Ericaceae. VIII. The role of mycorrhizal infection in heavy metal resistance. New Phytol. 91, 669682.

Brooks, R.R., 1998. General introduction. In: Brooks, R.R. (Ed.), Plants that Hyperaccumulate Heavy Metals. CAB International, Wallingford, UK, pp. 1-14.

Brown, M.T., Wilkins, D.A., 1985. Zinc tolerance of mycorrhizal Betula. New Phytol. 99, 101-106.

Heggo, A., Angle, J.S., Chaney, R.L., 1990. Effects of vesiculararbuscular mycorrhizal fungi on heavy metal uptake by soybeans. Soil Biol. Biochem. 22, 865-869.

Hetrick, B.A.D., Wilson, G.W.T., Figge, D.A.H., 1994. The influence of mycorrhizal symbiosis and fertilizer amendments on establishment of vegetation in heavy-metal mine spoil. Environ. Pollut. 86, 171-179.

Jakobsen, I., Joner, E.J., Larsen, J., 1994. Hyphal phosphorus transport, a keystone to mycorrhizal enhancement of plant growth. In: Gianinazzi, S., Schüepp, H. (Eds.), Impact of Arbuscular Mycorrhizas on Sustainable Agriculture and Natural Ecosystems. Birkhauser, Basel, Switzerland, pp. 133-146.

Jones, M.D., Hutchinson, T.C., 1988a. Nickel toxicity in mycorrhizal birch seedlings infected with Lactarius rufus or Scleroderma flavidum. 1. Effects on growth, photosynthesis, respiration and transpiration. New Phytol. 108, $451-459$.

Jones, M.D., Hutchinson, T.C., 1988b. Nickel toxicity in mycorrhizal birch seedlings infected with Lactarius rufus or Scleroderma flavidum. 2. Uptake of nickel, calcium, magnesium, phosphorus and iron. New Phytol. 108, 461-470.

Li, X.L., George, E., Marschner, H., 1991. Phosphorus depletion and $\mathrm{pH}$ decrease at the root-soil and hyphaesoil interfaces of VA mycorrhizal white clover fertilised with ammonium. New Phytol. 119, 397-404.

McGonigle, T.P., Miller, M.H., Evans, D.G., Fairchild, G.L., Swan, J.A., 1990. A new method which gives an objective measure of colonization of roots by vesicular-arbuscular mycorrhizal fungi. New Phytol. 115, 495-501. 
McGrath, S.P., 1987. Long-term studies of metal transfers following application of sewage sludge. In: Coughtrey, P.J., Martin, M.H., Unsworth, M.H. (Eds.), Pollutants Transport and Fate in Ecosystems. Blackwell, Oxford, pp. 310-317.

Ministry of Agriculture, Fisheries and Food, 1986. The Analysis of Agricultural Materials. MAFF/ADAS Reference Book 427, HMSO, London.

Shetty, K.G., Hetrick, B.A.D., Schwab, A.P., 1995. Effects of mycorrhizae and fertilizer amendments on zinc tolerance of plants. Environ. Pollut. 88, 307-314.

Smith, S.E., Read, D.J., 1997. Mycorrhizal Symbiosis, second ed. Academic Press, London, pp. 153-154.

Thompson, J.P., 1996. Correction of dual phosphorus and zinc deficiencies of linseed (Linum usitatissimum L.) with cultures of vesicular-arbuscular mycorrhizal fungi. Soil Biol. Biochem. 28, 941-951.

Wasserman, J.L., Mineo, L., Majumdar, S.K., Vantyne, C., 1987. Detection of heavy metals in oak mycorrhizae of northeastern Pennsylvania forests, using X-ray microanalysis. Can. J. Bot. 65, 2622-2627.

Weissenhorn, I., Leyval, C., Berthelin, J., 1995. Bioavailability of heavy metals and abundance of arbuscular mycorrhiza in a soil polluted by atmospheric deposition from a smelter. Biol. Fert. Soils 19, 22-28.

Zhu, Y.G., Laidlaw, A.S., Christie, P., Hammond, M.E.R., 2000. The specificity of arbuscular mycorrhizal fungi in perennial ryegrass-white clover pasture. Agri. Ecosys. Environ. 77, 211-218. 